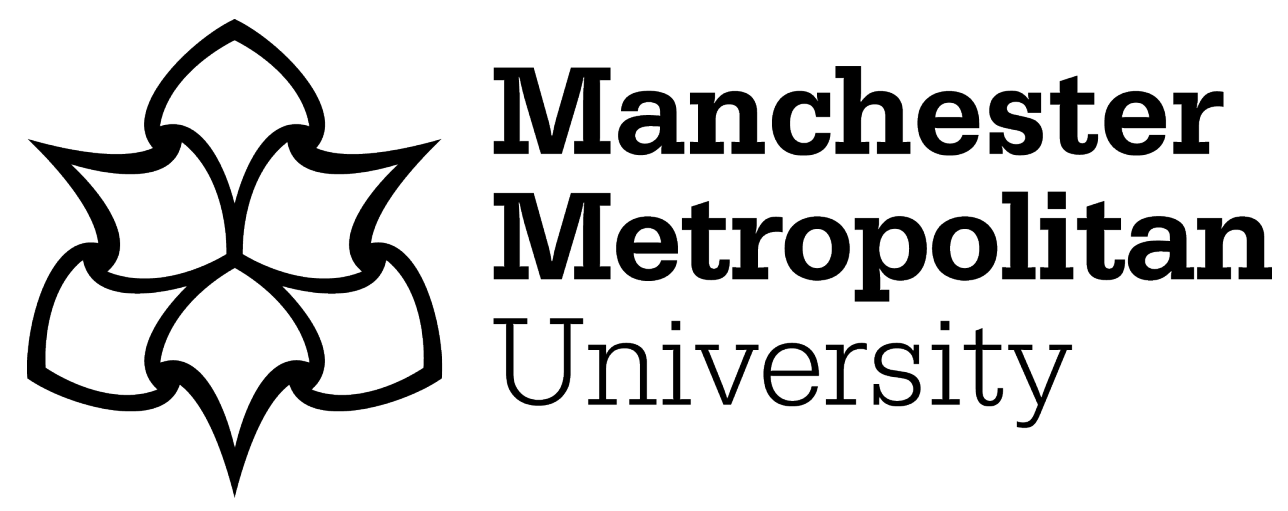

Shulla, K, Leal Filho, W, Lardjane, S, Sommer, JH and Borgemeister, C (2020) Sustainable development education in the context of the 2030 Agenda for sustainable development. International Journal of Sustainable Development and World Ecology, 27 (5). pp. 458-468. ISSN 1350-4509

Downloaded from: https://e-space.mmu.ac.uk/625146/

Version: Accepted Version

Publisher: Taylor \& Francis

DOI: https://doi.org/10.1080/13504509.2020.1721378

Please cite the published version 


\section{Sustainable development education in the context of the 2030 Agenda for sustainable development}

Shulla K, Leal Filho W, Lardjane S, Sommer JH, Borgemeister. C

International Journal of Sustainable Development and World Ecology 01 Jan 2020 DOI

https://www.tandfonline.com/doi/full/10.1080/13504509.2020.1721378

\section{Abstract}

Education for Sustainable Development (ESD) is a concept that evolves in line with emerging sustainability issues. In the 2030 Agenda for Sustainable Development, ESD is embraced in Goal 4, Target 4.7, and reflected in other Goals and Targets. The approach towards the 2030 Agenda is important, not only because of the crucial role that education will play in the implementation of the Goals, but also in increasing its impact by orienting towards the emerging sustainability challenges. Therefore, there is a high demand for research to better understand ESD interactions with the 2030 Agenda framework in specific contexts. This study addresses the implications of Target 4.7 on the 17 Sustainable Development Goals, in the context of the Regional Centres of Expertise on Education for Sustainable Development as global multi-stakeholder networks. It analyzes the interaction of Target 4.7 with other Goals and Targets, in order to identify the strongest connections amongst thematic sustainability issues. The findings revealed through statistical analyses and a comprehensive literature review, that the prevailing components of ESD are strongly interconnected with Goals 2, 3, 4, 7, 11, $12,13,15$. Thus reinforcing that the multidimensional aspects of ESD in relation to the SDGs are stronger regarding the current complex issues such as, education, climate, energy, sustainable cities, natural habitat, consumption and production. Although the nature of multistakeholder networks allows for diverse approaches of ESD towards the 2030 Agenda, the study indicates the importance of partnership and informal learning for reflection of global sustainability issues in regional platforms.

Keywords: education for sustainable development; SDGs; targets; frameworks 


\section{Introduction}

Education for Sustainable Development (ESD) is an evolving concept, whose many interpretations are relevant to local and national circumstances, as it adapts to the specifics of political, socio-cultural, and ecological contexts (UNESCO 2017). This concept reached major recognition during the United Nations (UN) Decade on Education for Sustainable Development (DESD) (2004-2014), with the adoption of the 2030 Agenda for Sustainable Development. ESD is embraced by Goal 4, Target 4.7 of this plan, "By 2030, ensure that all learners acquire the knowledge and skills needed to promote sustainable development, including, among others, through Education for Sustainable Development and sustainable lifestyles, human rights, gender equality, promotion of a culture of peace and nonviolence, global citizenship and appreciation of cultural diversity and of culture's contribution to sustainable development" (UN 2015).

Nevertheless, the concept and values of ESD is diffused throughout all 17 Sustainable Development Goals (SDGs). Other Targets related to education (according to the SDGEducation 2030 Steering Committee Secretariat) namely "Education within the 2030 Agenda for Sustainable Development" are: Target 3.7, SDG3, "Health and well-being", Target 5.6, SDG5, "Gender equality", Target 8.6, SDG8, "Decent work and economic growth", Target 12.8, SDG12, "Responsible consumption and production" and Target 13.3, SDG 13, "Climate change mitigation" (https://sdg4education2030.org/the-goal).

The UN Educational, Scientific and Cultural Organization (UNESCO), the global leader of data for education, is responsible for 22 measurement indicators that significantly contribute to SDG4 concerning quality of education. The dissemination of the progress of these indicators is done through the UNESCO Institute for Statistics (UIS) databases. There are 232 Indicators for the 17 SDGs, and the role of international institutions appointed as "custodian" 
agencies is to collect data from national sources and compile internationally comparable estimates (UNDESA 2017). Some of the Indicators cover more than one Goal, which requires the development of new assessment methodologies (Casini 2019).

The importance of education for the 2030 Agenda is acknowledged in the six transformations needed to achieve SDGs proposed by Sachs et al. (2019). The first transformation emphasises the need for three sets of interventions: (1) to promote education, (2) to reach gender equality, and (3) to decrease inequality. Due to the interdependence of sustainability challenges across SDGs, a successful implementation of Goal 4 (which is also considered to be a means of implementation across the entire 2030 Agenda) can influence the success of other Goals (Leal Filho 2019). ESD can sustain the future impact of the SDGs through its social dimension that enables cultural reproduction and a holistic interpretation of knowledge (UNESCO 2018a). Although recognized in Target 4.7, there is insufficient clarity within the set of indicators to demonstrate achievements for ESD. Thus, among the requirements needed for ESD in relation to the SDGs framework, intrapersonal competences and an emphasis on non-formal learning is integral to success (Giangrande et al. 2019).

The 2030 Agenda, due to the sustainable development thematic issues that it contains, encourages sustainability research (Leal Filho 2018). Research for the ESD, as an integral element of SDG 4, becomes more crucial when considering the contribution of education to all the Goals. Nevertheless, the ambiguity of ESD impact, and the complex and indivisible character of the 2030 Agenda, increases the need for understanding these interrelations which can be achieved through mapping and measuring the interactions between the Goals and Targets in specific contexts. The SDG Summit in September 2019 stressed the need for new scientific research and its subsequent adoption to specific local and regional contexts in order to exploit Goal synergies and look beyond 2030 (UN 2019). 
This study describes the evolution of ESD over the last two decades through a comprehensive literature review. The interconnection of Target 4.7 with other goals is analysed, with the purpose of identifying the areas where ESD can have the strongest contribution towards several thematic sustainability issues embraced in the 2030 Agenda. A statistical analysis of interactions between Target 4.7 with a group of selected targets is done with the aim of illustrating the strongest interactions on the target level.

Data were collected through a survey conducted within the network of the Regional Centres of Expertise on Education for Sustainable Development (RCEs). ESD is recognized for accelerating and advancing sustainable solutions at a local level, i.e. via multi-stakeholder networks such as the RCEs which were acknowledged by United Nations University Institute of Advanced Studies (UNU IAS) during the UN Decade on ESD (UNU-IAS 2014). The ESD Programme at UNU-IAS has created a global network of more than 150 RCEs worldwide. "The RCEs provide a framework for strategic thinking and action on sustainability by creating diverse partnerships among educators, researchers, policymakers, scientists, youth, leaders within indigenous communities and throughout the public, private and non-governmental sectors" (UNU-IAS 2018b).

The purpose of this paper is to explore the role of ESD in the 2030 Agenda by examining the interconnections of Target 4.7 with the rest of the Goals and Targets in the context of multi-stakeholder networks. Based on the findings, literature reviews and authors' reflections, the study provides insights into the prevailing issues of ESD toward SDGs, in the context of diverse networks, for a better understanding of potential future interpretations of ESD under the umbrella of the 2030 Agenda. 


\section{Defining Education for Sustainable Development (ESD)}

UNESCO's definition of ESD states that “Education for Sustainable Development empowers learners to make informed decisions and responsible actions for environmental integrity, economic viability and a just society for present and future generations, while respecting cultural diversity" (UNESCO 2009). ESD embraces the crucial role that education plays in sustainable development. Until 1992, ESD was seen primarily as environmental education. With the 1992 UN Conference on Environment and Development (UNCED) in Rio de Janeiro and the Framework for Action of Agenda 21, ESD expanded and merged all forms of education, including environmental, social, ethical and cultural dimensions (UN 1992).

ESD achieved major recognition during the DESD, adopted by the UN General Assembly at its 57 th session in 2002, with UNESCO designated as the lead agency for promotion throughout the following decade. It is important to mention that since 1992 UNCED has laid the basis for the UN Decade on ESD (Leal Filho 2015). In its "Future we want" document, the Rio+20 UN Conference on Sustainable Development in 2012 promoted the relevance of ESD beyond the ESD decade. "We resolve to promote education for sustainable development and to integrate sustainable development more actively into education beyond the Decade of Education for Sustainable Development”(UN 2012). Several Millennium Development Goals (MDGs) were related to ESD, which is considered to be an important instrument for organizations to achieve the MDGs (Wals and Kief 2010).

During the DESD, there were considerable efforts to integrate sustainable development into all aspects of learning, resulting in an increase in their appearance in national policies and international agreements. The importance of ESD for behaviour change for a sustainable future through engaging a wide range of stakeholders (from governments, the private sector, civil 
society, non-governmental organisations and the general public) was explicitly recognized (UNESCO 2014a).

At the end of the DESD, the Global Action Program (GAP) on ESD (2015-2019) was launched by UNESCO as an official follow-up, focusing in generating and scaling up actions on the ground. This programme was based on five priority areas; advancing policy, transforming learning and training environments, building capacities of educators and trainers, mobilizing youth, and accelerating sustainable solutions at local levels as well as aiming to accelerate progress towards the SDGs (UNESCO 2014b).

Currently, a framework created by UNESCO on ESD entitled "Education for Sustainable Development: Towards achieving the SDGs (ESD for 2030)" is in process. This framework was developed in order to build a post-GAP position that will contribute to the Agenda 2030 through: 1) continuation of support for ESD activities that contribute to SDGs, even without explicit reference, 2) communication and advocacy in educational settings with explicit reference to SDGs, and 3) ESD importance in addressing interlinkages between SDGs (UNESCO, 2019).

The core of ESD is the application in all levels of formal, non-formal and informal education as an integral part of lifelong learning. The International Standard Classification of Education defines formal education as what takes place in the education system of a country (either institutionalized, intentional and planned, through public organizations and recognized private bodies); Non-formal education is an alternative to formal education within the process of lifelong learning (guaranteeing the right of access for all without any formal recognition by the education authorities); on the other hand, Informal education is learning that is not institutionalized and less organized or structured than either formal or non-formal education, including learning activities that occur everywhere and in daily life, on a self or sociallydirected basis (UIS 2012). 
Nevertheless, ESD is a dynamic concept that contains crucial issues for sustainable development (such as climate change, biodiversity, sustainable production and consumption, and reduction of poverty) and relies on stakeholders to use education as an instrument to achieve sustainable development, and education stakeholders to integrate sustainability principles into education systems (UNESCO 2018b).

Different fields of education, such as environmental education, global education, economics education, development education, multicultural education, conservation education, outdoor education, global change education, among others, are complemented by education in sustainability (Leal Filho 2009).

Furthermore, ESD explores Global Citizenship for Sustainable Development (GCED), also included in Target 4.7. While ESD focuses more on environmental issues, GCED is more concerned with issues such as human rights, democracy, conflict and peace (https://en.unesco.org/themes/gced/definition). The concept of global citizenship in GCED is critical, calling for proactive engagement for sustainable development, compared to the softer global citizenship component in ESD (Chung and Park 2016). ESD and Sustainability Science (SS) can be complementary. SS emphasises the scientific transition toward sustainability, while ESD orients the education system towards sustainability, both aiming for a systemic knowledge through inter- and transdisciplinary and multi-stakeholder approaches (Arico 2014). ESD can be complemented by other disciplines such as Citizens Science, which is the involvement of individuals in scientific processes (Kullenberg and Kasperowski 2016). While Citizens Science enables subject competence and empowerment of citizens (Pettibone et al. 2016) ESD encourages responsible choices and healthy lifestyles. ESD can foster sustainability transition, through the variety of stakeholders. 


\section{Methodology}

This study is based on a comprehensive literature review, statistical analysis and analytical reflections by the authors. The data were collected through a survey conducted between April to July 2018, within the global network of 159 RCEs using a list-based sampling frame. The questionnaire was also published in the RCEs e-bulletin (Global RCE Network, 2018) and on the Facebook Page of the Global RCEs Network. The survey (supplemental information [SI] Table 5) was voluntary and anonymous and consisted of 25 questions divided into four sections. For the purpose of this study only questions 6, 7 and 8, of section 1 "RCEs and their involvement with the SDGs" were used, as they provided the relevant information and insights needed for the analyses of the current involvement of the RCEs with the 17 SDGs; Targets and Indicators in general and Targets of Goal 4 in particular. Data on the contribution of RCEs in the implementation of the 2030 Agenda was also collected during the survey and these findings have been published in a previous paper by the authors Shulla et al. (2019).

The analysis of the results is divided into two sections. Section (a) analyses the interactions of Target 4.7 with the most selected Goals by the RCEs. The purpose is to identify interconnections by illustrating the network representations. Descriptive statistics and Network Representation analyses were conducted with the support of software R (R. Core Team 2013). Section (b) assesses the most influencing and influenced targets in the context of RCEs, by using the 'Goal Interaction Scoring on a Seven-Point Scale' framework; a typology and scoring of interaction as a conceptual basis for a science-based assessment (Table 1) (Nilsson et al. 2017; ICSU 2017).

Table 1. Goal Interaction Scoring on a Seven-Point Scale explained and labelled according to their interactions (Nilsson et al. 2017; ICSU 2017) 


\begin{tabular}{|c|c|c|}
\hline $\begin{array}{l}\text { Interact } \\
\text { ion }\end{array}$ & Label & Explanation \\
\hline+3 & Indivisible & $\begin{array}{l}\text { Progress on one target automatically delivers progress on } \\
\text { another }\end{array}$ \\
\hline+2 & Reinforcing & $\begin{array}{l}\text { Progress on one target makes it easier to make progress on } \\
\text { another }\end{array}$ \\
\hline+1 & Enabling & $\begin{array}{l}\text { Progress on one target creates conditions that enable } \\
\text { progress on another }\end{array}$ \\
\hline \pm 0 & Consistent & There is no significant link between two targets' progress \\
\hline-1 & Constraining & $\begin{array}{l}\text { Progress on one target constrains the options for how to } \\
\text { deliver on another }\end{array}$ \\
\hline-2 & Counteracting & $\begin{array}{l}\text { Progress on one target makes it more difficult to make } \\
\text { progress on another }\end{array}$ \\
\hline-3 & Cancelling & $\begin{array}{l}\text { Progress on one target automatically leads to a negative } \\
\text { impact on another }\end{array}$ \\
\hline
\end{tabular}

This framework allows the identification of the most positive or negative interactions, providing insights for the RCEs future actions and creating a basis for identification of common indicators applicable to a group of Goals. This framework is applied by using the cross-impact matrix at the Target's level, a methodological approach previously developed by Weitz et al. (2018). The weighting process is based on the author's judgement. To analyse and illustrate the network representations, specifically the relation of Target 4.7 with the rest of the targets of the matrix, further Network Representation analyses were conducted with the support of software R (R. Core Team 2013). Conclusions and findings were discussed using further literature reviews and authors reflections.

\section{Results}


There were a total of 31 replies to the survey, from the sample size of 159 RCEs. The response rate from the participants concerning the survey questions were: $100 \%$ for the questions 6 and 8 , and $42 \%$ for the question 7 . The results are presented in two sections: a) The interaction of Target 4.7 with the 17 Goals in the context of the RCEs network, and b) Target interactions in the context of RCEs network.

\section{a) The interaction of target 4.7 with 17 Goals in the context of RCEs network}

This study identifies that the most used Goals by the RCEs are Goals 4, 13, 15, 7, 6, 12, 11 and 17. Table 2. shows the ranking of the SDG 4 Targets, identifying the use of the Target 4.7 by the majority of the respondents $(84 \%)$.

Table 2. Involvement of the RCEs with the Targets of SDG 4, measured in numbers and percentage. (31 RCEs in total)

\begin{tabular}{|c|c|}
\hline SDG4 Targets & Number of RCEs [\%] \\
\hline 4.7 Education for sustainable development and global citizenship & $26 \quad[84 \%]$ \\
\hline 4.c Teachers and educators & $17 \quad[55 \%]$ \\
\hline 4.a Effective learning environments & $14[45 \%]$ \\
\hline 4.3 Equal access to technical/vocational and higher education & $12[39 \%]$ \\
\hline 4.5 Gender equality and inclusion & $11 \quad[35 \%]$ \\
\hline 4.1 Universal primary and secondary education & $10 \quad[32 \%]$ \\
\hline 4.4 Relevant skills for decent work & $10 \quad[32 \%]$ \\
\hline 4.6 Universal youth literacy & $5 \quad[16 \%]$ \\
\hline 4.2 Early childhood development and universal pre-primary education & $4 \quad[13 \%]$ \\
\hline 4.b Scholarships & $1 \quad[3 \%]$ \\
\hline
\end{tabular}

Further analysis based on the above information for the most used Goals and Targets are displayed in Figure 1, identifying the proportion of RCEs that use Target 4.7 in relation to the 17 Goals. The relation of Target 4.7 with the 17 SDGs is represented by a network plot, with target 4.7 at the centre. In the network plot, the width of an edge is proportional to the number of RCEs who use target 4.7 and the goal at the same time. The strongest links with Target 4.7 
appears to be with the Goals 4,13, 7, 11, 15 and 12. It illustrates the multidimensional aspects of ESD in relation to other Goals.

Figure 1. The relation of Target 4.7 with the 17 SDGs. The strength or thickness of a link reflects the proportion of RCEs who use at the same time Target 4.7 and the respective Goals (Target 4.7 is positioned in the centre).

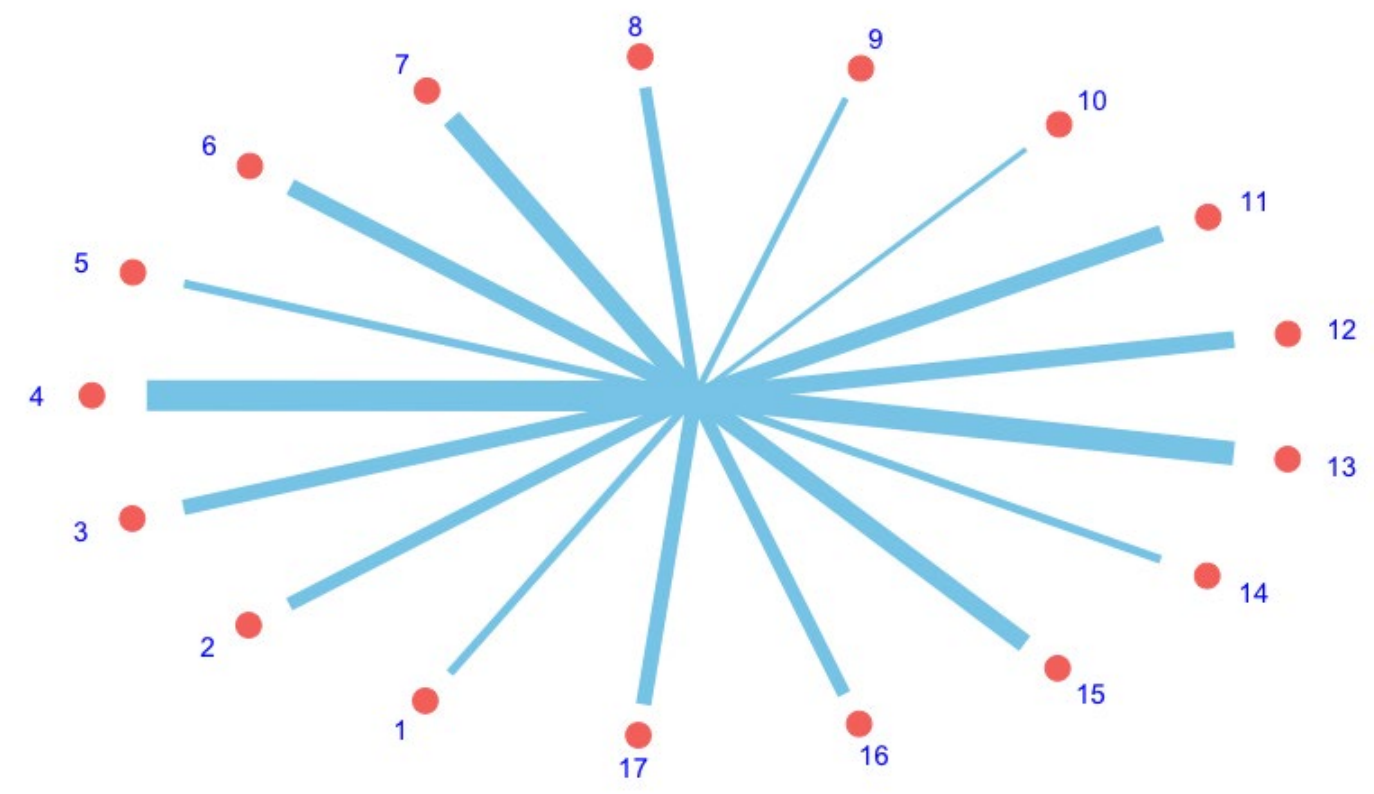

\section{b) Target interactions in the context of RCEs network}

There is insufficient information on the involvement of the RCEs that participated in this study with the SDGs Targets and Indicators. There was a relatively low response rate to survey question 7 (see SI, Table 4.) on their engagement with Targets and Indicators. Specifically, there is information only on their involvement with Targets and Indicators of Goal 4 (see Table 2). 
Nevertheless, analyses of Targets interactions in the RCEs context are crucial to establishing a common ground and coordinating actions for SDGs. For this reason, 27 Targets were selected based on the results of the most commonly used Goals by the RCEs, taking into consideration the focus and the field of expertise of the participating RCEs. The Targets were weighted based on the authors' judgement, using the "Goal Interaction Scoring on a Seven-Point Scale" framework. The values are displayed in the Targets Matrix in Figure 2.

Figure 2. Matrix of 27x27 Targets

\begin{tabular}{|c|c|c|c|c|c|c|c|c|c|c|c|c|c|c|c|c|c|c|c|c|c|c|c|c|c|c|c|c|}
\hline & 23 & 24 & 3.7 & $3 . d$ & 4.3 & 4.7 & 4.2 & $4 . c$ & 6.6 & 6.b & 7.3 & 7.3 & 11.3 & 11.4 & 11.6 & 12.1 & 12.6 & 128 & $12 . \mathrm{b}$ & 13.1 & 13.3 & 15.5 & $15 . \mathrm{e}$ & 17.6 & 17.14 & 17.16 & \begin{tabular}{|l|l|}
17.17 \\
\end{tabular} & \\
\hline 2.3 & & 3 & 0 & 0 & 1 & 0 & 0 & 0 & 0 & 1 & 1 & 1 & $a$ & 0 & 1 & 1 & 1 & 1 & 2 & 2 & 1 & 0 & 1 & 0 & 0 & 0 & 0 & 17 \\
\hline 2.4 & 3 & & 0 & 3 & 1 & 2 & 0 & 0 & 2 & 2 & 2 & 1 & 2 & 1 & 2 & 1 & 2 & 1 & 2 & 3 & 3 & 2 & 1 & 0 & 1 & 1 & 0 & 37 \\
\hline 3.7 & 1 & 1 & & 3 & 2 & 3 & 1 & 2 & 0 & 1 & 0 & 0 & $a$ & 0 & 0 & 0 & 0 & 2 & 0 & $a$ & 0 & 0 & 0 & 1 & 1 & 1 & 1 & 20 \\
\hline 3.d & a & 0 & 3 & & 1 & 2 & 2 & 2 & 0 & 3 & 0 & 0 & 1 & 0 & 2 & $a$ & 1 & 2 & 1 & 1 & 1 & 0 & 0 & 1 & 2 & 1 & 0 & 26 \\
\hline 4.3 & 2 & 2 & 2 & 3 & & 3 & 1 & 1 & 1 & 1 & 1 & 1 & 1 & 1 & 1 & 0 & 1 & 2 & 1 & 1 & 1 & 1 & 1 & 0 & 1 & 0 & 0 & 30 \\
\hline 4.7 & 2 & 2 & 3 & 3 & 2 & & 1 & 3 & 1 & 1 & 1 & 1 & 1 & 1 & 1 & 0 & 1 & 3 & 1 & 1 & 1 & 1 & 1 & 0 & 0 & 0 & 0 & 33 \\
\hline 4.a & $a$ & 0 & 0 & 0 & 0 & 2 & & 2 & 0 & 0 & 2 & 2 & 0 & 0 & 0 & 0 & 0 & 1 & 0 & $a$ & 1 & 1 & 0 & 0 & 1 & 0 & 0 & 12 \\
\hline 4.c & 1 & 1 & 2 & 3 & 2 & 2 & 2 & & 1 & 1 & 0 & 0 & 1 & 1 & 1 & 1 & 0 & 2 & 1 & 1 & 2 & 1 & 1 & 0 & 1 & 0 & 0 & 28 \\
\hline 6.6 & -1 & 1 & 0 & 0 & 1 & 1 & 1 & 1 & & 1 & 1 & 1 & 2 & 3 & 2 & 1 & 1 & 1 & 1 & 1 & 1 & 3 & 3 & 2 & 1 & 1 & 1 & 31 \\
\hline 6.6 & 1 & 1 & 1 & 2 & 2 & 2 & 1 & 1 & 2 & & 1 & 1 & 2 & 2 & 2 & 1 & 1 & 2 & 1 & 1 & 2 & 2 & 1 & 1 & 2 & 0 & 0 & 35 \\
\hline $7 . \mathrm{a}$ & 1 & 2 & 0 & 1 & 3 & 3 & 2 & 1 & 2 & 1 & & 3 & 1 & 0 & 2 & 1 & 1 & 1 & 1 & 1 & 2 & 3 & 1 & 1 & 2 & 2 & 2 & 40 \\
\hline 7.3 & 2 & 2 & 0 & 0 & 1 & 1 & 1 & 1 & 2 & 0 & 3 & & 1 & 1 & 2 & 1 & 2 & 1 & 1 & 1 & 1 & 2 & 1 & 0 & 0 & 0 & 0 & 27 \\
\hline 11.3 & 1 & 2 & 2 & 2 & 1 & 1 & 2 & 1 & 2 & 3 & 1 & 2 & & 3 & 3 & 1 & 1 & 1 & 2 & 2 & 1 & 2 & 0 & 0 & 3 & 0 & 3 & 42 \\
\hline 11.4 & 1 & 2 & 1 & 0 & 1 & 1 & 1 & 1 & 1 & 2 & 0 & 0 & 2 & & 1 & 0 & 1 & 2 & 2 & 1 & 2 & 2 & 2 & 0 & 2 & 0 & 2 & 30 \\
\hline 11.6 & 1 & 2 & 0 & 3 & 1 & 1 & 2 & 1 & 3 & 3 & 2 & 2 & 2 & 2 & & 1 & 2 & 1 & 2 & 2 & 2 & 2 & 1 & 1 & 3 & 2 & 2 & 46 \\
\hline 12.1 & 2 & 2 & 1 & 2 & 1 & 2 & 2 & 1 & 1 & 1 & 2 & 2 & 2 & 2 & 2 & & 2 & 2 & 1 & 2 & 2 & 2 & 1 & 2 & 3 & 3 & 2 & 47 \\
\hline 12.6 & 2 & 2 & 1 & 1 & 2 & 1 & 1 & 1 & 1 & 2 & 3 & 1 & 2 & 2 & 1 & 2 & & 1 & 1 & 2 & 1 & 2 & 1 & 2 & 2 & 1 & 1 & 39 \\
\hline 12.8 & 2 & 2 & 3 & 3 & 3 & 3 & 1 & 2 & 2 & 2 & 1 & 2 & 2 & 2 & 1 & 1 & 1 & & 2 & 1 & 3 & 2 & 1 & 1 & 3 & 2 & \begin{tabular}{|l|}
1 \\
\end{tabular} & 49 \\
\hline 12.6 & 3 & 3 & 1 & 2 & 1 & 2 & 1 & 2 & 2 & 1 & 1 & 2 & 2 & 2 & 1 & 1 & 1 & 2 & & 2 & 2 & 3 & 2 & 0 & 3 & 2 & 3 & 47 \\
\hline 13.1 & 2 & 2 & 1 & 3 & 2 & 3 & 2 & 2 & 2 & 2 & 2 & 2 & 2 & 2 & 3 & 2 & 2 & 2 & 1 & & 3 & 2 & 1 & 2 & 3 & 2 & 2 & 54 \\
\hline 13.3 & 2 & 2 & 2 & 3 & 3 & 3 & 3 & 3 & 2 & 2 & 1 & 2 & 2 & 2 & 2 & 2 & 2 & 3 & 1 & 3 & & 2 & 1 & 1 & 3 & 2 & 2 & 56 \\
\hline 15.5 & 1 & 2 & 0 & 1 & 1 & 1 & 1 & 1 & 3 & 2 & 1 & 1 & 1 & 3 & 2 & 1 & 1 & 2 & 2 & 1 & 2 & & 2 & 1 & 3 & 1 & 1 & 38 \\
\hline $15 . \varepsilon$ & 2 & 2 & 1 & 2 & 2 & 2 & 1 & 1 & 3 & 2 & 0 & 1 & 1 & 3 & 1 & 1 & 2 & 2 & 2 & 1 & 1 & 3 & & 3 & 2 & 3 & 2 & 46 \\
\hline 17.6 & 2 & 2 & 2 & 2 & 3 & 1 & 1 & 1 & 2 & 2 & 2 & 2 & 2 & 2 & 3 & 2 & 2 & 2 & 1 & 2 & 2 & 2 & 2 & & 2 & 3 & 3 & 52 \\
\hline $\begin{array}{l}17.1 \\
4\end{array}$ & 2 & 2 & 3 & 2 & 3 & 3 & 2 & 2 & 3 & 3 & 2 & 3 & 3 & 2 & 2 & 3 & 3 & 3 & 2 & 3 & 3 & 2 & 2 & 1 & & 2 & 3 & 64 \\
\hline $\begin{array}{l}17.1 \\
6\end{array}$ & 2 & 2 & 2 & 2 & 2 & 2 & 1 & 2 & 2 & 2 & 3 & 3 & 2 & 2 & 2 & 3 & 2 & 2 & 2 & 3 & 2 & 1 & 3 & 3 & 2 & & 3 & 57 \\
\hline \multirow[t]{2}{*}{$\frac{17.1}{7}$} & 2 & 2 & 2 & 2 & 2 & 2 & 3 & 2 & 2 & 3 & 3 & 2 & 3 & 2 & 2 & 3 & 3 & 3 & 3 & 2 & 3 & 2 & 1 & 3 & 3 & 3 & & 63 \\
\hline & 36 & 44 & 30 & 46 & 41 & 45 & 34 & 36 & 39 & 45 & 35 & 36 & 40 & 40 & 42 & 30 & 34 & 47 & 36 & 38 & 44 & 44 & 31 & 26 & 49 & 32 & 34 & \\
\hline
\end{tabular}

Matrix is in Target level (Weitz et al. 2018) and weighting is done by Seven-Point Scale Goals interaction method (-3, Cancelling, makes it impossible to reach another goals), (-2 Counteracting, clashes with another goal), (-1, Constraining, limits option on another goal), ( 0 , Consistent, no significant positive or negative interaction), $(+1$, Enabling, create conditions that further another goal), (+2, Reinforcing, aids the achievement of another goal), (+3, Indivisible, inextricably linked to the achievement of another goal) (Nilsson et al. 2016; ICSU 2017). The most eminent values are identified as -1 (red), neutral as 0 (pink), and +3 (blue). The matrix has a non-reciprocal character. The direction of the weighting is from the targets column to the targets row. The row of Target 4.7 is identified in bold to show the data used for further analyses. The overall scores horizontally show the total influence from a target to other targets. The overall scores vertically show how much a target is influenced by all targets in total. 
The weighting is based on the question: "If progress is made on target $x$ (rows), how does this influence progress on targety (columns)', (Weitz et al. 2018). The higher the sum in the column the more positively the Target is influenced by other Targets. The higher the sum in the rows the more the Target positively influences other Targets.

In general, Targets of Goal 17 and Goal 4 received the most points for positively influencing other Targets in the RCEs context. An example which would illustrate this process would be if Target 4.c (row) "by 2030, substantially increase the supply of qualified teachers, including through international cooperation for teacher training in developing countries, especially least developed countries and small island developing States" progresses, it can positively influence Target 3.d (column) "Strengthen the capacity of all countries, in particular developing countries, for early warning, risk reduction and management of national and global health risks" due to the priority of teachers and educators in specific trainings outside the ordinary curricula in many RCEs projects.

The most influencing Targets (in rows) belonged to Goals 17, 12, 3, 4, 13, and 15, and the most influenced Targets (in columns) to Goals 17, 13, 12, and 11. Selected Indicators that belong to the most influenced and influencing Targets are summarised in Supplementary Information (SI) Table 5. A major part of these Indicators belong to Tier III, according to the Tier Classification for Global SDG Indicators (UNDESA 2019), meaning that no internationally established methodology or standards are yet available, but will be developed. These Indicators can be considered by RCEs in order to redefine their objectives, or can be included in their impact evaluation frameworks.

Although the explanations behind each weighting are not included in this study, Table 3 displays the scoring process for Target 4.7 toward other Targets. For this evaluation, we also considered flagship projects and best practices of RCEs across formal and informal educational 
sectors, cultivating participatory and change-oriented learning environments (UNU-IAS

2018a) and contribution to health and wellbeing for a sustainable future (UNU-IAS 2018b).

Table 3. Explanations behind the scoring for the influence of the Target 4.7 (column) towards

the 27 Targets (rows) as displayed in the Matrix in Figure 2.

\begin{tabular}{|c|c|c|c|c|}
\hline Targets 4.7 & $\begin{array}{l}\text { Targ } \\
\text { ets }\end{array}$ & Target Description & $\begin{array}{c}\text { Eva } \\
\text { luat } \\
\text { ion } \\
(-3- \\
3 \\
\text { poi } \\
\text { nts) }\end{array}$ & Explanation \\
\hline \multirow{10}{*}{$\begin{array}{l}4.7 \text { By 2030, } \\
\text { ensure that all } \\
\text { learners } \\
\text { acquire the } \\
\text { knowledge and } \\
\text { skills needed to } \\
\text { promote } \\
\text { sustainable } \\
\text { development, } \\
\text { including, } \\
\text { among others, } \\
\text { through } \\
\text { Education for } \\
\text { Sustainable } \\
\text { Development } \\
\text { and sustainable } \\
\text { lifestyles, } \\
\text { human rights, } \\
\text { gender equality, } \\
\text { promotion of a } \\
\text { culture of peace } \\
\text { and } \\
\text { nonviolence, } \\
\text { global } \\
\text { citizenship and } \\
\text { appreciation of } \\
\text { cultural } \\
\text { diversity and of } \\
\text { culture's } \\
\text { contribution to } \\
\text { sustainable } \\
\text { development". }\end{array}$} & \multirow{2}{*}{2.3} & \multirow{2}{*}{$\begin{array}{l}\text { By 2030, double the agricultural productivity } \\
\text { and incomes of small-scale food producers, in } \\
\text { particular women, indigenous peoples, family } \\
\text { farmers, pastoralists and fishers, including } \\
\text { through secure and equal access to land, other } \\
\text { productive resources and inputs, knowledge, } \\
\text { financial services, markets and opportunities } \\
\text { for value addition and non-farm employment }\end{array}$} & 2 & $\begin{array}{l}\text { RCEs partners are often farms or small enterprises related to } \\
\text { food production. Several RCEs work with indigenous } \\
\text { communities and women. It does not obtain the maximal points } \\
\text { due to other factors such assess to the resources. }\end{array}$ \\
\hline & & & & \\
\hline & 2.4 & $\begin{array}{l}\text { By } 2030 \text {, ensure sustainable food production } \\
\text { systems and implement resilient agricultural } \\
\text { practices that increase productivity and } \\
\text { production, that help maintain ecosystems, } \\
\text { that strengthen capacity for adaptation to } \\
\text { climate change, extreme weather, drought, } \\
\text { flooding and other disasters and that } \\
\text { progressively improve land and soil quality }\end{array}$ & 2 & $\begin{array}{l}\text { RCEs focus on traditional knowledge for food production } \\
\text { systems and agricultural practices. They contribute to increase } \\
\text { awareness through working with communities. }\end{array}$ \\
\hline & 3.7 & $\begin{array}{l}\text { By } 2030 \text {, ensure universal access to sexual } \\
\text { and reproductive health-care services, } \\
\text { including for family planning, information } \\
\text { and education, and the integration of } \\
\text { reproductive health into national strategies } \\
\text { and programmes }\end{array}$ & 3 & $\begin{array}{l}\text { The Targets are positively interrelated through the education } \\
\text { component. RCEs contribute to awareness raising and } \\
\text { information sharing about the issues of Target } 3.7 \text {, with schools } \\
\text { and communities. Furthermore, RCEs can work on reflecting } \\
\text { these issues into school curricula, as one of their objectives is to } \\
\text { influence and orient school curricula toward sustainability. }\end{array}$ \\
\hline & 3.d & $\begin{array}{l}\text { Strengthen the capacity of all countries, in } \\
\text { particular developing countries, for early } \\
\text { warning, risk reduction and management of } \\
\text { national and global health risks }\end{array}$ & 3 & $\begin{array}{l}\text { The RCEs make considerable contributions in influencing } \\
\text { policies and increasing capacity strengthening related to the } \\
\text { health issues. }\end{array}$ \\
\hline & 4.3 & $\begin{array}{l}\text { By } 2030 \text {, ensure equal access for all women } \\
\text { and men to affordable and quality technical, } \\
\text { vocational and tertiary education, including } \\
\text { university }\end{array}$ & 2 & $\begin{array}{l}\text { RCE work is focused on different levels of education, including } \\
\text { vocational training. But the access of women and men also } \\
\text { depend on other factors. }\end{array}$ \\
\hline & 4.7 & & & \\
\hline & 4.a & $\begin{array}{l}\text { Build and upgrade education facilities that are } \\
\text { child, disability and gender sensitive and } \\
\text { provide safe, non-violent, inclusive and } \\
\text { effective learning environments for all }\end{array}$ & 1 & $\begin{array}{l}\text { Examples from RCEs projects indicate for an integrated } \\
\text { approach in projects related to schools and education, e.g. } \\
\text { raising awareness for effective learning environments, by } \\
\text { introducing and implementing measures for reducing their } \\
\text { environmental footprints.https://edufootprint.interreg- } \\
\text { med.eu/news-events/news/detail/actualites/green-schools- } \\
\text { sixth-edition/). }\end{array}$ \\
\hline & 4.c & Teachers and educators & 3 & $\begin{array}{l}\text { Priority for teachers' and educators' specific training in } \\
\text { sustainability issues outside the official curricula, e.g. the RCEs } \\
\text { Opeducaraject } \quad \text { with } \quad \text { schools } \\
\text { (https://www.opeduca.eu/The OPEDUCA_Project.html). }\end{array}$ \\
\hline & 6.6 & $\begin{array}{l}\text { By } 2020 \text {, protect and restore water-related } \\
\text { ecosystems, including mountains, forests, } \\
\text { wetlands, rivers, aquifers and lakes }\end{array}$ & 1 & $\begin{array}{l}\text { Contribute to the awareness raising (individual and institutional) } \\
\text { for the importance of the issues. }\end{array}$ \\
\hline
\end{tabular}




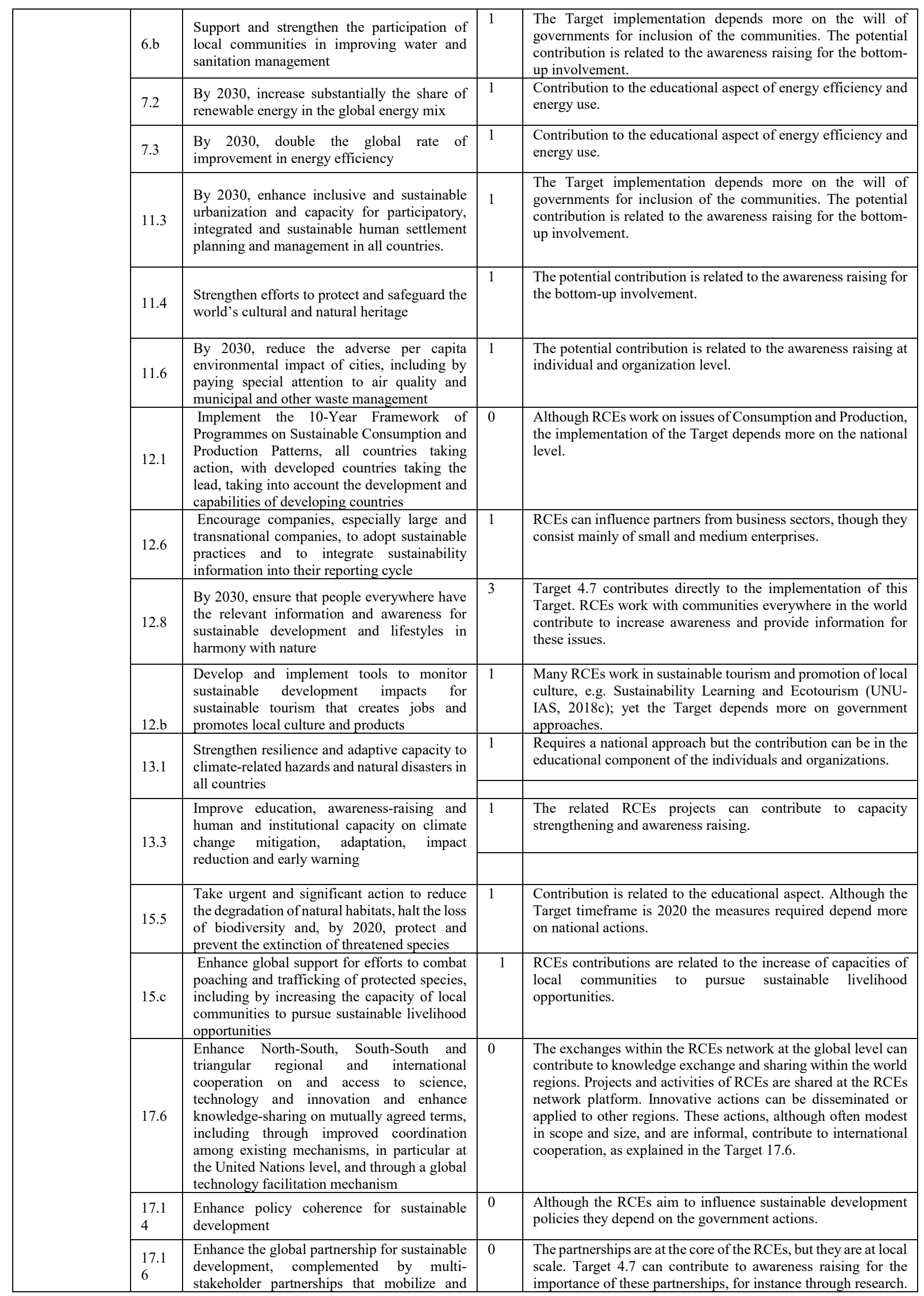




\begin{tabular}{|l|l|l|l|l|}
\hline & $\begin{array}{l}\text { share knowledge, expertise, technology and } \\
\text { financial resources, to support the achievement } \\
\text { of the sustainable development goals in all } \\
\text { countries, in particular developing countries }\end{array}$ & $\begin{array}{l}\text { Encourage and promote effective public, } \\
\text { public-private and civil society partnerships, } \\
\text { building on the experience and resourcing } \\
\text { strategies of partnerships. }\end{array}$ & $\begin{array}{l}\text { RCEs promote effective partnerships through ESD, which can } \\
\text { be of multi-stakeholders but not necessary involving public } \\
\text { institutions. } \\
\text { The Indicator 17.17.1 "Amount of United States dollars } \\
\text { committed to public-private and civil society partnership" } \\
\text { appears to measure initiatives funded by public institutions. }\end{array}$ \\
\hline
\end{tabular}

Figure 3. further visualises results from the Targets matrix in Figure 2. and illustrates the interconnection of Target 4.7 with the rest of the selected Targets. The network plot identifys the strength of the links between the different targets based on the calculation of data displayed in the relationship matrix in Figure 2. Target 4.7 is positioned at the center. The width of each edge reflects the strength of the positive influence of Target 4.7 with the other Targets. The strongest interconnection appears to be with Targets 4.8, 4.c, 3.d, 3.7, 2.4, 2.3. 12.8, 12.b, and 15.5

Figure 3. Network representation of the links of Target 4.7 with other targets. The network plot identify the strength of the links between the different targets based on the calculation of the data as displayed in the relationship matrix in Figure 2. Target 4.7 is positioned at the centre. The width of each edge reflects the strength of the positive influence of Target 4.7 with the other Targets. 


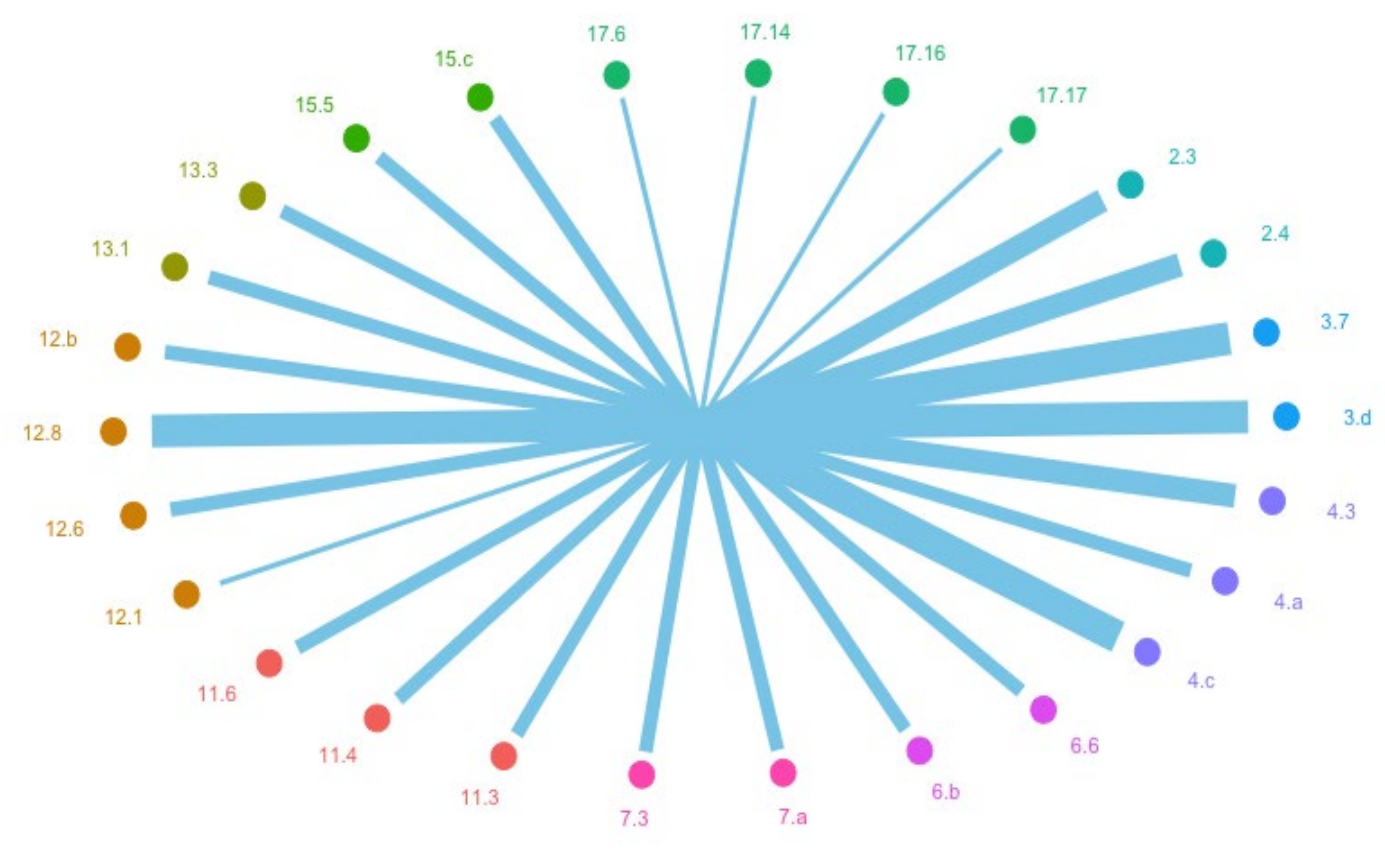

\section{Conclusions and Discussion}

ESD is a dynamic concept that includes all actions and challenges towards sustainable development, and is at the core of global goals for a sustainable future. RCEs multi-stakeholder global networks are adopting their strategies and working programs according to the 2030 Agenda, through the prioritization of relevant SDG thematic areas and translating them into regional contexts through ESD, such as education, climate, energy, sustainable cities, natural habitat and responsible consumption and production (Shulla et al. 2019).

This study substantially contributes to research on the approach of ESD toward the 2030 Agenda for Sustainable Development. It particularly addresses the implications of Target 4.7 on the 17 SDGs, based on the evidence of the current actions of multi-stakeholder SDG networks. In addition, it highlights research gaps for the interactions between SDGs Targets in specific contexts. We identified a list of SDGs Targets with positive interdependence, indicating the strongest components of ESD in relation to emerging global issues. This should 
be considered in future planning and strategies by RCEs and similar networks and organisations.

We suggest the strongest elements for the RCEs approach toward the 2030 Agenda through ESD, such as 1) partnerships, 2) informal learning and 3) thematic focus.

(1) Partnerships: Partnerships for sustainable development are considered crucial to the implementation of the SDGs, as it is explicitly expressed in Goal 17. In fact, several targets of SDG 17 are among the most influencing and influenced Targets in the RCEs context (see SI Table 5).

ESD has served as a connecting element for partnerships through the work of RCEs since 2005. Mainstreaming ESD in the framework of 2030 Agenda can contribute to network-building amongst the network partners, such as civil society, business, academia, communities, and local governments. The network partnerships may continue to be a priority in the post-Gap "ESD for 2030 approach" (UNESCO 2019) and partnerships for ESD and multi-stakeholder colearning are related to the implementation of ESD in all levels of governance (Wals et al. 2017).

(2) Informal learning: The analyses of the potential Targets influences (see Table 3) (also identified informal learning component of ESD) is strongly reflected in the RCEs work with communities, which in the light of the 2030 Agenda can add a substantial contribution to their approach towards the SDGs. The impact of informal learning is often invisible and difficult to measure. There is also insufficient research for the informal component of ESD, this is due to the fact that it is mainly promoted through formal education, neglecting the informal education connection with community development (Noguchi 2015).

(3) Thematic focus: ESD's orientation toward several SDGs thematic issues would require RCEs around the world to align their focus and local agendas to the current sustainability challenges. RCEs worldwide involvement with SDGs, using their unique 
approach through ESD, can facilitate a further integration of ESD into the SDGs framework. Identifying and understanding the sustainability issues, prominent now and in the future, remain crucial aspects of ESD (Lambrechts and Hindson 2016). Grouping the SDGs Targets and Indicators based on the analyses of their strongest interactions, as displayed in Table 5, can help to avoid divisions during the implementation process. Encouraging organizations and networks that work on local solutions through ESD to integrate and align their programs with the SDGs framework can contribute to a clear reflection and understanding of the current sustainability challenges, and can avoid separate agendas, therefore allowing for an integrated approach toward the 2030 Agenda for Sustainable Development. At Target level (Figure 3.), this study shows a strong link between Target 4.7 and Targets 2.3, 2.4, 3.7, and 3.d, revealing additional components of ESD relevant to the SDGs thematic issues of Goal 3 "health" and Goal 2 "hunger", which were not evident from the analyses at Goal level (Figure 1). While the analysis at Goals level was based on data collected from the RCE survey, the analyses at Targets level resulted from data generated from the Targets Matrix (see Figure 2).

Altogether, it is challenging to shape non-formal education related to sustainability issues, especially for adults. Nevertheless, this can be achieved through information campaigns and job training (UNU-IAS 2016). The complexities of climate change education can be fully addressed by ESD components (MoChizuki and Bryan 2015).

The sustainability debate has recently gained momentum and public attention. The "Fridays for Future movement" of students campaigning for immediate action on climate change, for example, has fuelled the global conversation https://www.unenvironment.org/championsofearth/laureates/2019/fridays-future-movement. 
This offers an opportunity to weave ESD concepts into mainstream society at many different levels and may even push governments towards the implementation of meaningful policies which address and implement the 2030 Agenda for Sustainable Development in a credible manner.

\section{Limitations of the study and implications for theory and practise}

There are some limitations related to this study, such as the relatively small sample size of the RCE survey. Greater participation from the RCEs community would have allowed for a deeper analysis. Consequently, information on the RCEs involvement with specific Targets and Indicators was limited. The weighting process for Target interactions is context dependent, and was influenced by the judgement of the authors. Lastly, the study does not consider the possible negative influences of contradicting Targets, and their potential implications for the role of ESD in the 2030 Agenda.

This study contributes to research on the approach of ESD toward the 2030 Agenda for Sustainable Development. It particularly addresses the implications of Target 4.7 on the 17 SDGs, based on the evidence of the current actions of multi-stakeholder networks. In addition, it highlights research gaps for the interactions between SDGs Targets in specific contexts.

Finally, the study identifies a list of SDGs Targets with positive interdependence, indicating the strongest components of ESD in relation to emerging global issues; this should be considered in future planning and strategies by RCEs and similar networks and organisations.

\section{References}


1. Arico S. 2014. The contribution of the sciences, technology and innovation to sustainable development: the application of sustainability science from the perspective of UNESCO's experience. Sustain Sci. 9. p.453-462.

2. Casini M, Bastianoni S, Gagliardi F, Gigliotti M, Riccaboni A, Betti G. 2019. Sustainable Development Goals indicators: A methodological proposal for a multidimensional fuzzy index in the Mediterranean area. Sustainability. 11(4), 1198.

3. Chung BG, Park I. 2016. A review of the differences between ESD and GCED in SDGs: focusing on the concepts of global citizenship education. Journal of International Cooperation in Education. 18 (2). p. 17-35. CICE Hiroshima University, Japan.

4. Giangrande N, White RM, East M, Jackson R, Clarke T, Saloff Coste M, Penha-Lopes G. 2019. A competency framework to assess and activate education for sustainable development: addressing the UN Sustainable Development Goals 4.7 Challenge. Sustainability. 11(10), 2832.

5. Kullenberg C, Kasperowski D. 2016. What is citizen science?-A scientometric metaanalysis. PloS One. 11 (1).p. e0147152.

6. Lambrechts W, Hindson J. 2016. Research and Innovation in education for sustainable development. Exploring collaborative networks, critical characteristics and evaluation practices. ENSI, ZVR-Zahl 408619713. Vienna, Austria.

7. Leal Filho W. 2009. Towards the promotion of education for sustainability. Rev. Educ. 33. P. 263-277.

http://citeseerx.ist.psu.edu/viewdoc/download?doi=10.1.1.598.9759\&rep=rep1\&type= pdf (accessed 2019, March 5).

8. Leal Filho W, Manolas E, Pace P. 2015. The future we want: key issues on sustainable development in higher education after Rio and the UN decade of education for sustainable development. IJSHE. 16 (1). p.112-129.

9. Leal Filho W, Tripathi SK, Andrade Guerra, JBSOD, Giné-Garriga R, Orlovic Lovren V, Willats J. 2019. Using the sustainable development goals towards a better understanding of sustainability challenges. INT J SUST DEV WORLD. 26(2).p. 179190.

10. Leal Filho W, Azeiteiro U, Alves F, Pace P, Mifsud M, Brandli L, Caeiro SS, Disterheft A. 2018. Reinvigorating the sustainable development research agenda: the role of the sustainable development goals (SDG), INT J SUST DEV WORLD. 25(2).p.131-142.

11. Mochizuki Y, Bryan A. 2015. Climate change education in the context of education for sustainable development: rationale and principles. JESD. 9 (1). p. 4-26.

12. Nilsson M. 2017. Important interactions among the Sustainable Development Goals under review at the high-level political forum 2017. SEI Working Paper 2017-06. Stockholm Environment Institute. Stockholm.

13. Noguchi F. 2018. Critical reflections on the UNDESD: From the perspectives of informal education in a community development context. JESD. 11(2).p. 141-151.

14. Pettibone L, Vohland K, Bonn A, Richter A, Bauhus W, Behrisch B, Borcherding R, Brandt M, Bry F, Doerdler F, et al. 2016. Citizen science for all, a guide for citizen science practitioners. GEWISS. Berlin. https://www.buergerschaffenwissen.de/sites/default/files/grid/2017/11/21/handreichun ga5 engl_web.pdf. (accesed 2019, November 1).

15. $\mathrm{R}$ Core Team. 2013. R: a language and environment for statistical computing. $\mathrm{R}$ Foundation for Statistical Computing, Vienna, Austria. URL http://www.Rproject.org/.

16. Sachs JD, Schmidt-Traub G, Mazzucato M, Messner D, Nakicenovic N, Rockström J. 2019. Six Transformations to achieve the Sustainable Development Goals. Nat Sustain. 2. p. 805-814. 
17. Shulla K, Leal Filho W, Lardjane S, Henning Sommer J, Lange Salvia A, Borgemeister C. 2019. The contribution of regional centers of expertise for the implementation of the 2030 Agenda for Sustainable Development. JLCP. 237. 117809.

18. [ICSU] International Social Science Council. 2017. A guide to SDG interactions: from science to implementation. In: International Council for Science. Paris. https://council.science/cms/2017/05/SDGs-Guide-to-Interactions.pdf (accessed 2019, April 29).

19. [UN] United $\quad$ Nations. $1992 . \quad$ Agenda 21. https://sustainabledevelopment.un.org/outcomedocuments/agenda21. (accessed 2019, October 29).

20. [UN] United Nations. 2012. Future we want. https://sustainabledevelopment.un.org/content/documents/733FutureWeWant.pdf. (accesed 2019, November 1).

21. [UN] United Nations. 2015. Transforming our world: the 2030 Agenda for Sustainable Development.

$\mathrm{A} / \mathrm{RES} / 70 / 1$. https://sustainabledevelopment.un.org/content/documents/21252030\%20Agenda $\% 20 \mathrm{f}$ or\%20Sustainable\%20Development\%20web.pdf. (accesed 2019, November 2).

22. [UN] United Nations. 2019. The future is now science for achieving sustainable development. Global sustainable development report. https://sustainabledevelopment.un.org/content/documents/24797GSDR report 2019. pdf. (accesed 2019, November 7).

23. [UNDESA] United Nations Department of Economic and Social Affairs, Statistics Division. 2017. https://unstats.un.org/sdgs/dataContacts/. (accesed 2019, November 2).

24. [UNDESA] United Nations Department of Economic and Social Affairs, Statistics Division. 2019. https://unstats.un.org/sdgs/iaeg-sdgs/tier-classification/. (accessed 2019, January 7).

25. [UNESCO] United Nations Educational, Scientific and Cultural Organization. 2009. Learning for a sustainable world: review of contexts and structures for education for sustainable development. www.unevoc.unesco.org/up/DESD_key_findings_and_way_forward_23March09.pdf. (accessed 2019, March 8).

26. [UNESCO] United Nations Educational, Scientific and Cultural Organization. 2014a. Shaping the Future We Want: UN Decade for Sustainable Development (2005-2014) Final Report. Paris, France. https://sustainabledevelopment.un.org/content/documents/1682Shaping\%20the $\% 20$ fut ure\%20we\%20want.pdf. (accesed 2019, November 1).

27. [UNESCO]. United Nations Educational, Scientific and Cultural Organization 2014b. Roadmap for Implementing the Global Action Programme on Education for Sustainable Development, http://unesdoc.unesco.org/images/0023/002305/230514e.pdf (accessed 8 March 2019).

28. [UNESCO] United Nations Educational, Scientific and Cultural Organization. 2017. Education for Sustainable Development Goals Learning Objectives. https://www.unesco.de/sites/default/files/2018-

08/unesco_education_for_sustainable_development_goals.pdf. Accesed 2019, November 2).

29. [UNESCO]. United Nations Educational, Scientific and Cultural Organization. 2018a. Policy brief, Education for Sustainable Development and SDGs. https://en.unesco.org/sites/default/files/gap_pn1__esd_and_the_sdgs_policy_brief_6_page_version.pdf (accessed 2 March 2019). 
30. [UNESCO] United Nations Educational, Scientific and Cultural Organization. 2018b. Issues and trends in Education for Sustainable Development, Leicht, A. Heiss, J. Byun, W. J., eds, ISBN 978-92-3-100053-9.

31. [UNESCO] United Nations Educational, Scientific and Cultural Organization. 2019. SDG 4 - Education 2030: Part II, Education for Sustainable Development beyond 2019. https://unesdoc.unesco.org/ark:/48223/pf0000366797.locale=en. (accessed on 17 October 2019).

32. [UNESCO-UIS] United Nations Educational, Scientific and Cultural Organization Institute for Statistics. 2012. International Standard Classification of Education ISCED 2011, ISBN 978-92-9189-123-8 Ref: UIS/2012/INS/10/REV.

33. [UNU-IAS] United Nations University-Institute for Advanced Studies 2014. Building a Resilient Future through Multi-stakeholder Learning and Action: Ten Years of Regional Centres of Expertise on Education for Sustainable Development.

34. [UNU-IAS] United Nations University-Institute for Advanced Studies. 2016. Climate Change Education: From Critical Thinking to Critical Action. Policy Brief. 4. 2016. http://www.rcenetwork.org/portal/sites/default/files/UNU-IAS\%20PB\%204\%20\%208FEB\%20-\%20for\%20printing2.pdf) (accessed 2019, October 6).

35. [UNU-IAS] United Nations University-Institute for Advanced Studies. 2018a. Academia and Communities: Engaging for Change Innovation in Local and Global Learning Systems for Sustainability Learning Contributions of the Regional Centres of Expertise on Education for Sustainable Development. file:///C:/Users/kshulla/Desktop/Academia and Communities_FINAL.pdf. (accessed on 20 October 2019).

36. [UNU-IAS] United Nations University-Institute for Advanced Studies. 2018b. Ensure Healthy Lives and Promote Well-being for All Experiences of Community Health, Hygiene, Sanitation and Nutrition Learning Contributions of the Regional Centres of Expertise on Education for Sustainable Development. http://collections.unu.edu/eserv/UNU:6403/EnsureHealthyLives2018 ONLINE.pdf. (accessed on 20 October 2019).

37. Wals A, Kieft G. 2010. Education for sustainable development research overview. https://library.wur.nl/WebQuery/wurpubs/fulltext/161396. (accessed 2019, October 2).

38. Wals AEJ, Mochizuki Y, Leicht A. 2017. Critical case-studies of non-formal and community learning for sustainable development. Int Rev Educ. 63: 783. https://doi.org/10.1007/s11159-017-9691-9

39. Weitz N, Carlsen H, Nilsson M, Skanberg K. 2018. Towards systemic and contextual priority setting for implementing the 2030 Agenda. Sustain Sci. 13: 531. 